Kirk, G. S., The Greek Myths (Baltimore: Penguin, 1974).

Morford, Mark P. O., and Lenardon, Robert J., Classical Mythology (New York: Longman, 1971).

Rose, H. J., A Handbook of Greek Mythology (London: Dutton, 1960).

\section{Death of a Rain Forest}

\section{ANN COT TRELL FREE}
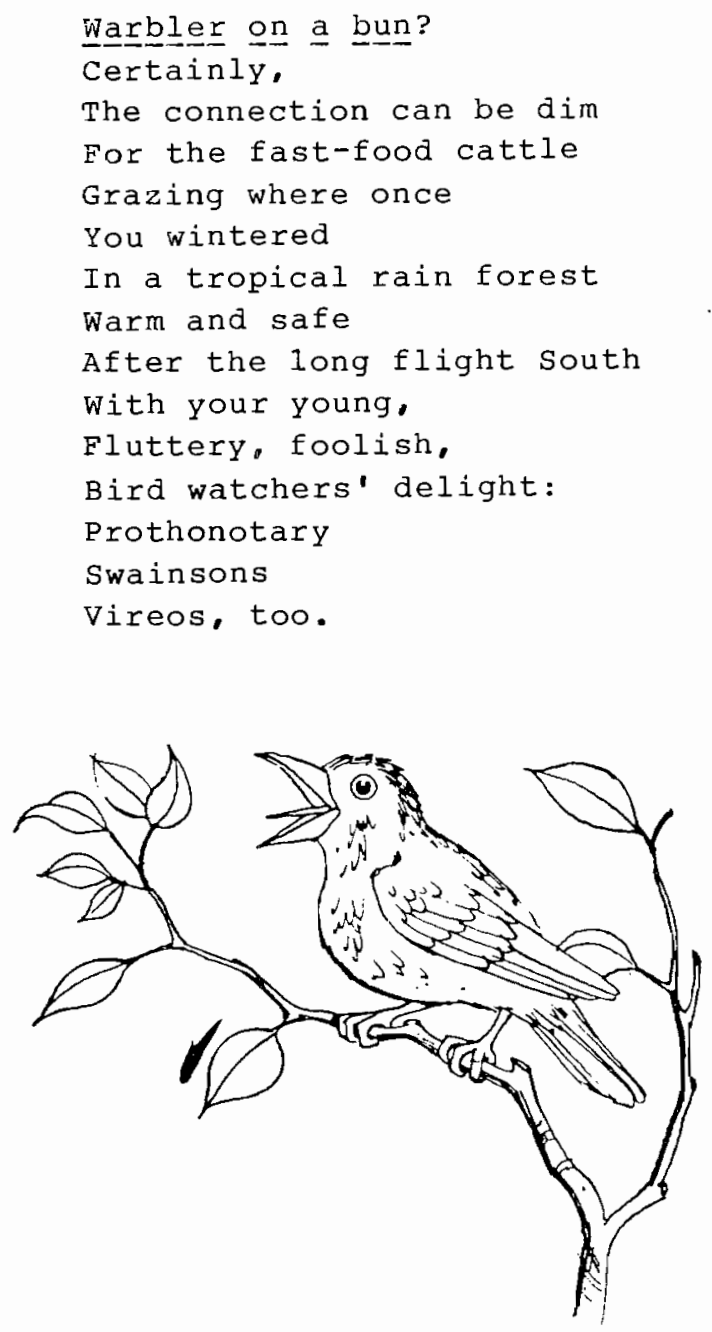

Youx home quite gone, Now, of course, Many of you.

Don't blame the cattle For taking your home; They don't eat hamburgers Any more than you. Only offer the ingredients For those who do.

\section{CALL FOR PAPERS}

\author{
SOCIETY FOR THE STUDY OF \\ EIHICS AND ANIMALS
}

Pacific Division Meeting San Francisco, California March 26, 1987

According to Peter Singer:

It is not arbitrary to hold that the life of a self-aware being, capable of abstract thought, of planning for the future, of complex acts of communication, and so on, is more valuable than the life of a being without these capacities. Animal Liberation, pp. 2i-22)

According to Tom Regan:

One cannot suppose that moral agents [or patients] have varying degrees of inherent value depending on the extent to which they possess some favored virtues. Inherent value is a categorical concept. One either has it, or one does not. There are no in-betweens. Moreover, all those who have it, have it equally. (The case for Animal Rights, pp. 246-7)

Papers on the topic of assessing the value of moral agents and patients are welcome for this program. (Papers need not be concerned with the work of Singer or Regan; the above quotations are offered only as ostensive clarifications of the topic of this call for papers.)

Those interested in contributing papers or in serving as commentators for this program should contact Steve Sapontzis at their earliest convenience:

Prof. Steve F. Sapontzis Department of Philosophy California State University Hayward, California 94542.

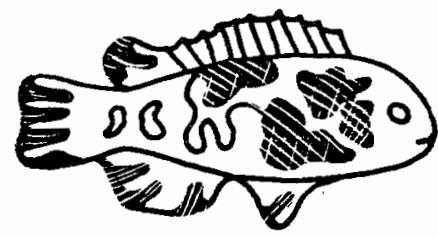

